\title{
Article \\ The Effect of C-Phycocyanin on Microglia Activation Is Mediated by Toll-like Receptor 4
}

\author{
Anna Piovan, Raffaella Filippini, Carla Argentini, Stefano Moro (D), Pietro Giusti and Morena Zusso * \\ Department of Pharmaceutical and Pharmacological Sciences, University of Padua, 35131 Padua, Italy; \\ anna.piovan@unipd.it (A.P.); raffaella.filippini@unipd.it (R.F.); carla.argentini@unipd.it (C.A.); \\ stefano.moro@unipd.it (S.M.); pietro.giusti@unipd.it (P.G.) \\ * Correspondence: morena.zusso@unipd.it; Tel.: +39-049-8275088
}

Citation: Piovan, A.; Filippini, R.; Argentini, C.; Moro, S.; Giusti, P.;

Zusso, M. The Effect of

C-Phycocyanin on Microglia Activation Is Mediated by Toll-like Receptor 4. Int. J. Mol. Sci. 2022, 23, 1440. https://doi.org/10.3390/ ijms 23031440

Academic Editors: Carmine Ostacolo, Diego Guidolin,

Sebastiano Mercadante,

Patrizia Russo and Andrea Angeli

Received: 5 January 2022

Accepted: 25 January 2022

Published: 27 January 2022

Publisher's Note: MDPI stays neutral with regard to jurisdictional claims in published maps and institutional affiliations.

Copyright: (C) 2022 by the authors. Licensee MDPI, Basel, Switzerland. This article is an open access article distributed under the terms and conditions of the Creative Commons Attribution (CC BY) license (https:// creativecommons.org/licenses/by/ $4.0 /)$.

\begin{abstract}
The blue-green alga Spirulina platensis is rich in phycocyanins, that exhibit a wide range of pharmacological actions. C-phycocyanin (C-PC), in particular, possesses hepatoprotective, nephroprotective, antioxidant, and anticancer effects. Furthermore, several studies have reported both antiand proinflammatory properties of this pigment. However, the precise mechanism(s) of action of $\mathrm{C}-\mathrm{PC}$ in these processes remain largely unknown. Therefore, here we explored the C-PC effect in in vitro microglia activation. The effect of C-PC on the expression and release of IL- $1 \beta$ and TNF- $\alpha$ and the activation of NF- $\mathrm{KB}$ was examined in primary microglia by real-time PCR, ELISA, and immunofluorescence. Treatment with C-PC up-regulated the expression and release of IL-1 $\beta$ and TNF- $\alpha$. C-PC also promoted the nuclear translocation of the NF- $\kappa B$ transcription factor. Then, to elucidate the molecular mechanisms for the immunoregulatory function of C-PC, we focused on investigating the role of Toll-like receptor 4 (TLR4). Accordingly, several TLR4 inhibitors have been used. Curcumin, ciprofloxacin, L48H37, and CLI-095 that suppresses specifically TLR4 signaling, blocked IL-1 $\beta$ and TNF- $\alpha$. Overall, these results indicate the immunomodulatory effect of C-PC in microglia cultures and show for the first time that the molecular mechanism implicated in this effect may involve TLR4 activation.
\end{abstract}

Keywords: C-phycocyanin; microglia; cytokines; Toll-like receptor 4

\section{Introduction}

The blue-green alga Arthrospira platensis, commonly known as Spirulina, has long been used as a food supplement mainly due to the high content of proteins $(\sim 70 \%$ by dry weight), vitamins, minerals, various kinds of amino acids, fibers, and pigments such as chlorophylls, carotenoids, and phycocyanins [1,2]. Apart from the importance as a food additive, currently, Spirulina is extensively studied for its potential for medical and therapeutic applications [2]. A lot of in vitro and in vivo studies have been focused on the antioxidant activity of Spirulina, that is able to activate antioxidant enzymes, scavenge free radicals and protect against lipid peroxidation and DNA damage [3-6]. Thanks to these activities, Spirulina is considered a promising agent with protective roles against renal, hepatic, cardiovascular, and central nervous system (CNS) diseases [7-9]. Spirulina has also immunomodulatory and anti-inflammatory properties. As stimulator of the immune system, Spirulina increases the macrophage phagocytic activity, activates T and B cells, and stimulates the production of antibodies and proinflammatory cytokines, such as interleukin (IL)-1 $\beta$, IL-2, IL-6, tumor necrosis factor (TNF)- $\alpha$, and interferon- $\gamma$ [10-12]. Spirulina exhibits also promising anti-inflammatory activities being able to inhibit the expression of inflammatory mediators, such as inducible nitric oxide synthase (iNOS), cyclooxygenase-2 (COX-2), TNF- $\alpha$, IL-1 $\beta$, and IL-6 in in vitro and in vivo models of inflammation [12-14]. The beneficial effects of Spirulina seem to be mediated by $\beta$-carotene, phycobiliproteins, and other vitamins and minerals present in the microalga $[15,16]$. Among the phycobiliproteins, 
Spirulina contains phycocyanin and allophycocyanin in a ratio of 10:1 [17]. In particular, C-phycocyanin (C-PC), isolated from the blue-green algae, is a nontoxic and noncarcinogenic water-soluble protein that constitutes up to $15-20 \%$ of Spirulina dry weight, and it is commonly used as a food additive, cosmetic colorant, and fluorescent dye [18]. C-PC also exhibits a wide range of pharmacological actions, including hepatoprotective, nephroprotective, antioxidant, and anticancer effects [19-21]. Furthermore, different studies have shown either anti- or proinflammatory effects of C-PC. For example, in macrophages and BV-2 microglia cells, C-PC reduced the expression of several inflammatory genes (e.g., iNOS, COX-2, TNF- $\alpha$, and IL-1 $\beta$ ) [22,23]. Conversely, Chen et al. [24] showed that C-PC induced secretion of TNF- $\alpha$, IL- $1 \beta$, and IL-6, increased expression of COX-2, and stimulated the phosphorylation of proteins implicated in inflammatory responses, including ERK, JNK, p38 and IкB in murine macrophages. Other studies also reported neuroprotective effects of $\mathrm{C}-\mathrm{PC}$ and showed that oral administration of C-PC crosses blood brain barrier suggesting its use in neurodegeneration, where oxidative stress and neuroinflammation play a relevant role $[25,26]$.

Neuroinflammation is initiated by microglia, the immune cells of the CNS, that in response to pathological conditions undergo an activation process aimed at CNS protection. Microglia activation is characterized by the classical (M1) and the alternative (M2) phenotype, although there are different opinions about the existence of multiple activation phenotypes for microglia. M1 microglia produce proinflammatory cytokines (e.g., TNF- $\alpha$, IL-1 $\beta$, IL-6), chemokines, and other mediators (nitric oxide, oxygen radicals), which contribute to the clearance of pathogens. Furthermore, M1 microglia are also able to perform phagocytosis, antigen presentation, and lymphocyte activation. On the other hand, M2 phenotype is associated with neural survival, suppression of brain damage, and prevention of negative effects of the immune response [27-30]. Importantly, microglia, like peripheral macrophages, are plastic cells that possess the capacity to change their phenotype during the inflammatory response [31,32]. Microglia become activated following interaction of pathogen- and/or endogenous damage-associated molecular patterns with pathogen recognition receptors, that include NOD-like receptors, C-type lectin receptors, RIG-I-like receptors, and Toll-like receptors (TLRs) [33,34]. Among the TLRs, TLR4, localized on the surface of microglia, is the major receptor for lipopolysaccharide (LPS), which is an important component of the outer membranes of Gram-negative bacteria [35]. Following activation, TLR4 interacts with the two adaptor proteins MyD88 and TRIF. Both MyD88dependent pathway and TRIF-dependent pathway result in the activation of nuclear factor $(\mathrm{NF})-\mathrm{KB}$, which induces the expression of proinflammatory genes and the production of cytokines [36,37].

Considering the conflicting results on the effect of C-PC in in vitro models of inflammation/neuroinflammation, in this study we explored the effect of C-PC in in vitro microglia activation. Then, with the purpose to clarify the mechanism involved in the observed effects, we found that microglia inflammatory response induced by C-PC was mediated by the activation of TLR4.

\section{Results}

\subsection{Identification of Noncytotoxic Concentrations of C-Phycocyanin in Microglial Cells}

The first experiments were aimed at exploring the safety and identifying the noncytotoxic concentrations of C-PC in microglia. Cultures were incubated with increasing concentrations $(1-300 \mu \mathrm{g} / \mathrm{mL})$ of a commercial preparation of C-PC for $16 \mathrm{~h}$. Cell viability of microglia exposed to C-PC at concentrations higher than $200 \mu \mathrm{g} / \mathrm{mL}$ significantly decreased compared to vehicle treated cells, taken as 100\% (Figure 1). Based on these results, concentrations of C-PC used in the following experiments ranged from 1 to $200 \mu \mathrm{g} / \mathrm{mL}$. 


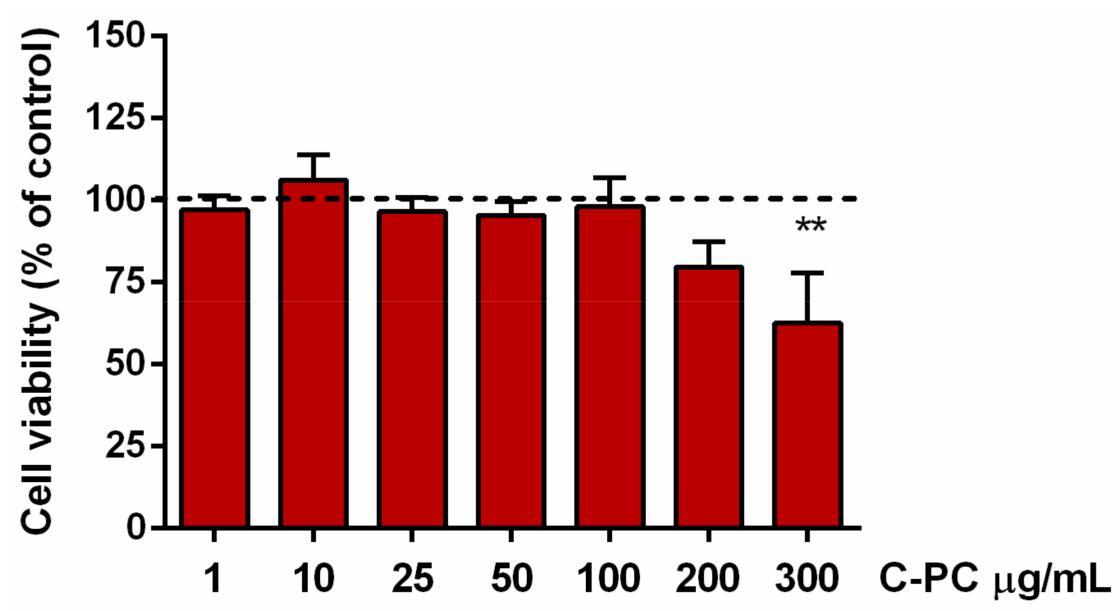

Figure 1. Effect of C-phycocyanin in microglia cell viability. Microglia were cultured overnight in medium containing $10 \%$ of serum, which was replaced with serum-free medium before exposure to C-PC $(1-300 \mu \mathrm{g} / \mathrm{mL})$ for $16 \mathrm{~h}$. At the end of incubation, SRB assay was used to measure cell viability. Results are expressed as percentage of cell viability relative to control cells. Data are means \pm SEM of 3 independent experiments. ${ }^{* *} p<0.01$ versus control cells (dashed line). One-way ANOVA followed by Holm-Sidak's test.

\subsection{Effect of C-Phycocyanin on Proinflammatory Cytokine Release by Microglia}

Classical M1 microglia activation is correlated with the production and release of proinflammatory cytokines such as IL- $1 \beta$ and TNF- $\alpha$, in addition to reactive oxygen species, nitric oxide, and others inflammatory mediators [29]. Therefore, to study the effect of C-PC on M1 microglia activation, cells were treated with noncytotoxic concentrations of C-PC (1-200 $\mu \mathrm{g} / \mathrm{mL})$ in the absence or presence of LPS stimulation, and the release of IL-1 $\beta$ and TNF- $\alpha$, indicative of M1 activation, was examined. C-PC significantly increased basal levels of both cytokines starting from the concentration of $25 \mu \mathrm{g} / \mathrm{mL}$ (Figure 2A,B). To note that the release of both cytokines induced by the highest concentrations of C-PC tested (100 and $200 \mu \mathrm{g} / \mathrm{mL}$ ) was to the same extent as that observed after stimulation with the endotoxin LPS, a potent inducer of M1 microglia activation. Furthermore, pretreatment with C-PC did not influence the release of IL-1 $\beta$ and TNF- $\alpha$ induced by LPS (Figure 2C,D).

To confirm these results, we also explored the effect of C-PC on IL-1 $\beta$ and TNF- $\alpha$ mRNA expression levels. Considering that 100 and $200 \mu \mathrm{g} / \mathrm{mL}$ C-PC affected cytokine release in a similar manner, in the following studies C-PC was used at the concentration of $100 \mu \mathrm{g} / \mathrm{mL}$. C-PC treatment markedly increased basal levels of cytokine gene expression, without changing the effect of LPS (Figure 3).

\subsection{Effect of C-Phycocyanin on NF- $\kappa B$ Activation in Microglia}

The transcription factor NF- $\mathrm{kB}$ is expressed in the cytoplasm of the majority of cells. The activated NF- $\mathrm{kB}$ dimers (p50/p65) translocate to the nucleus and bind to $\mathrm{KB}$ site of chromosome to induce transcription of NF- $\mathrm{KB}$ targeted genes. NF- $\mathrm{KB}$ controls the expression of more than 500 genes, which are involved in inflammatory responses [38,39]. Therefore, immunofluorescence analysis was performed to analyze the effect of C-PC on nuclear translocation of the NF- $\mathrm{kB} / \mathrm{p} 65$ subunit. Consistent with NF- $\mathrm{kB}$ activation, confocal images reveal a pronounced redistribution of $\mathrm{p} 65$ subunit from the cytoplasm to the nucleus after treatment with C-PC. Furthermore, as observed for cytokine release, C-PC did not change the effect of LPS (Figure 4). In addition, microglia morphology has not been affected by 90-min exposure to C-PC, LPS, or their association. 
A

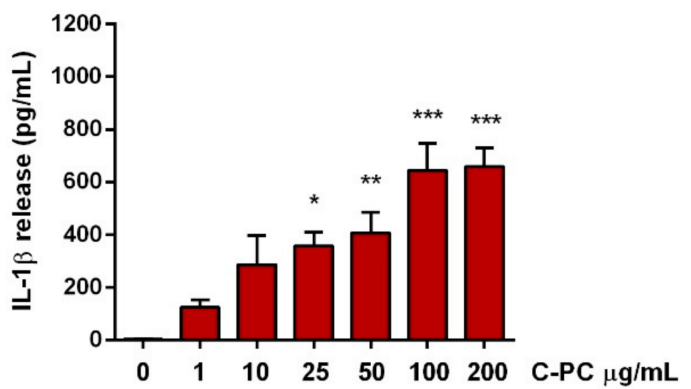

C

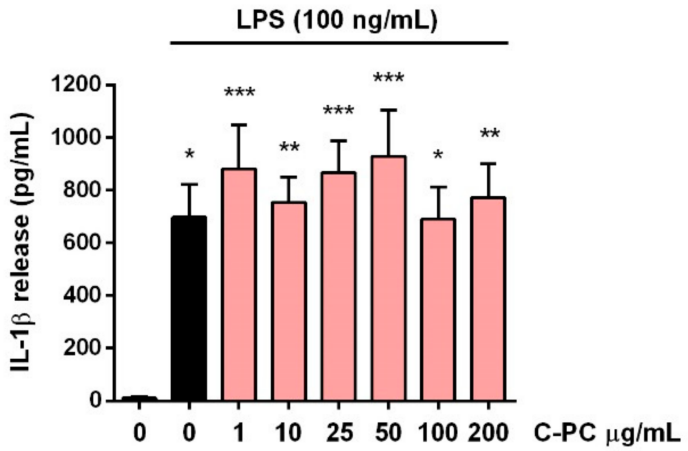

B

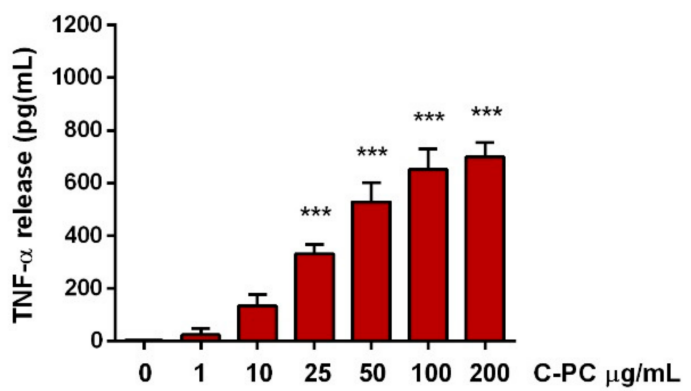

D

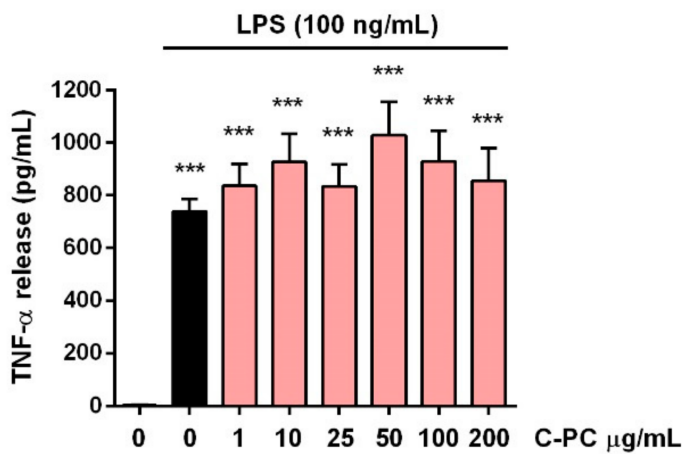

Figure 2. Effect of C-phycocyanin on cytokine release from cortical microglia. Microglia were cultured overnight medium containing $10 \%$ of serum, which was replaced with serum-free medium before treatment with C-PC (A,B) or C-PC + LPS $(100 \mathrm{ng} / \mathrm{mL})(\mathbf{C}, \mathbf{D})$. After the exposure to C-PC or LPS for $16 \mathrm{~h}$, supernatants were collected and analyzed for IL-1 $\beta(\mathbf{A}, \mathbf{C})$ and TNF- $\alpha(\mathbf{B}, \mathbf{D})$ content. Data are means $\pm \operatorname{SEM}\left(n=3\right.$ in triplicate). ${ }^{*} p<0.05,{ }^{* *} p<0.01$, and ${ }^{* * *} p<0.001$ versus control cells. One-way ANOVA followed by Holm-Sidak's test.

A

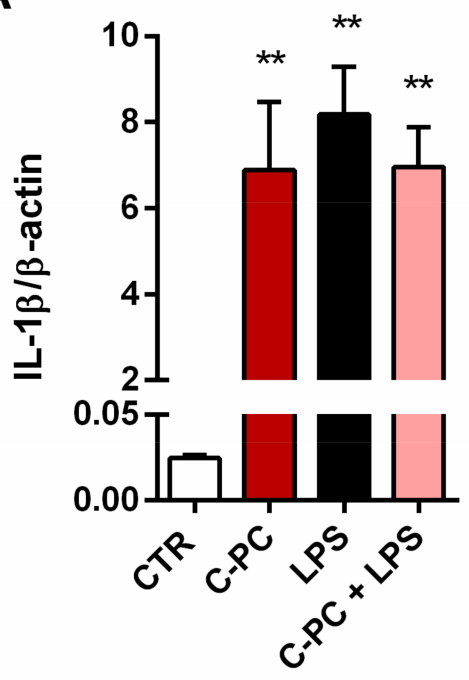

B

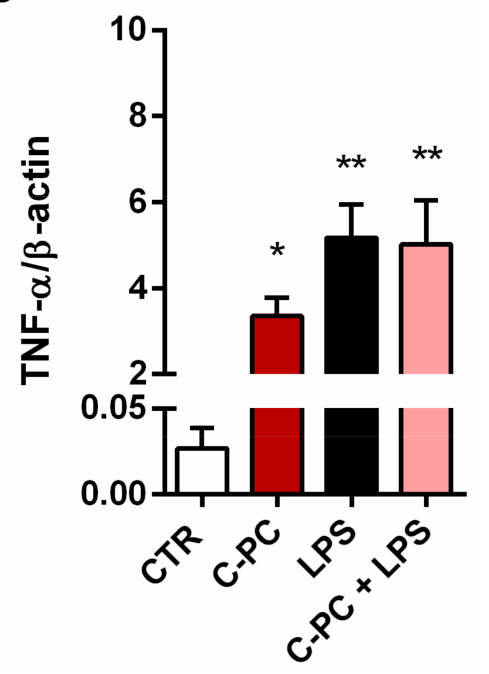

Figure 3. Effect of C-phycocyanin on cytokine production from cortical microglia. Microglia were cultured overnight in medium containing $10 \%$ of serum, which was replaced with serum-free medium before treatment with $100 \mu \mathrm{g} / \mathrm{mL}$ C-PC, $100 \mathrm{ng} / \mathrm{mL}$ LPS, or their association for $6 \mathrm{~h}$. IL-1 $\beta$ (A) and TNF- $\alpha$ (B) mRNA levels were quantified by real-time PCR. Data are means \pm SEM ( $n=3$ in triplicate). ${ }^{*} p<0.05$ and ${ }^{* *} p<0.01$ versus control cells (CTR). One-way ANOVA followed by Holm-Sidak's test. 

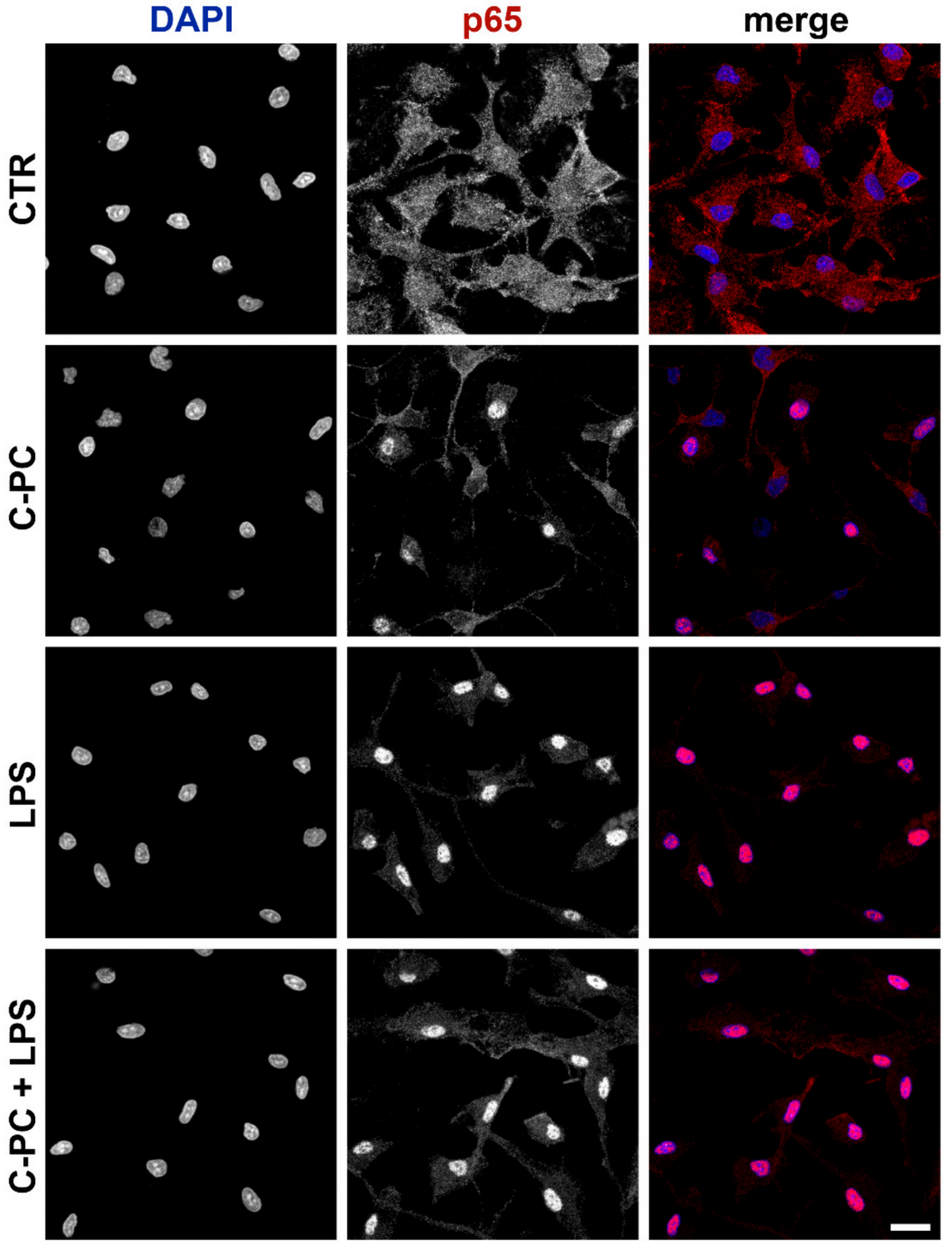

Figure 4. Effect of C-phycocyanin on NF- $\mathrm{kB}$ activation in microglia. Microglia were cultured overnight in medium containing $10 \%$ of serum, which was replaced with serum-free medium before treatment with $100 \mu \mathrm{g} / \mathrm{mL}$ C-PC $\pm 100 \mathrm{ng} / \mathrm{mL}$ LPS. Cells were then processed for NF-kB p65 immunostaining. Experiments were performed 3 times and representative confocal images showing subcellular localization of p65 are shown. Scale bar, $10 \mu \mathrm{m}$.

\subsection{Effect of Polymyxin B on Proinflammatory Cytokine Release by Microglia Treated with C-Phycocyanin}

In an attempt to explain the inconsistency between our results and some previous studies that have shown the anti-inflammatory properties of C-PC in macrophage and microglia cultures $[23,24]$, we examined whether C-PC could be contaminated with LPS. Microglia were pretreated with polymyxin B (PMB, $50 \mu \mathrm{g} / \mathrm{mL}$ ), a cyclic cationic polypeptide antibiotic able to bind to lipid A and neutralize LPS biological activity, widely used in vitro and in vivo to impede the effects of endotoxin contamination [40,41]. Then, cells were stimulated with $100 \mathrm{ng} / \mathrm{mL}$ LPS (used as positive control) or $100 \mu \mathrm{g} / \mathrm{mL}$ C-PC. As expected, PMB markedly abolished LPS-induced release of IL-1 $\beta$ and TNF- $\alpha$ by microglia (Figure 5, gray bars). Conversely, PMB had no effect on the release of both cytokines induced by C-PC (Figure 5, light red bars), proving that C-PC is free from endotoxin contamination. 
A

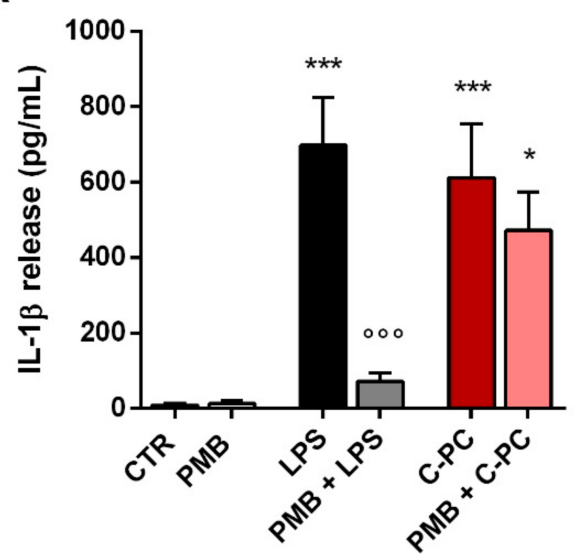

B

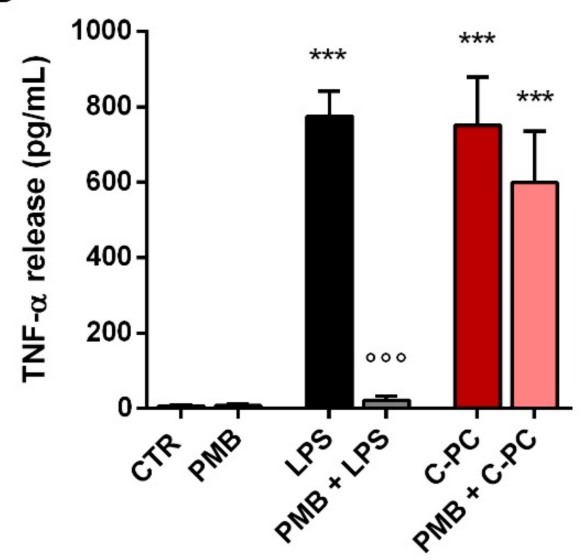

Figure 5. Effect of polymyxin B on cytokine release from cortical microglia. Microglia were cultured overnight in medium containing $10 \%$ of serum, which was replaced with serum-free medium before pretreatment with $50 \mu \mathrm{g} / \mathrm{mL}$ polymyxin B (PMB) for $1 \mathrm{~h}$ followed by stimulation with LPS $(100 \mathrm{ng} / \mathrm{mL})$ or C-PC $(100 \mu \mathrm{g} / \mathrm{mL})$ for $16 \mathrm{~h}$. Supernatant were collected and analyzed for IL-1 $\beta$ (A) and TNF- $\alpha$ (B) content. Data are means \pm SEM ( $n=4$ in triplicate). ${ }^{*} p<0.05$ and ${ }^{* * *} p<0.001$ versus control cells. ${ }^{\circ 00} p<0.001$ versus LPS treatment (black bars). One-way ANOVA followed by Holm-Sidak's test.

\subsection{Effect of Toll-Like Receptor 4 Inhibition on Proinflammatory Cytokine Release from Microglia Treated with C-Phycocyanin}

Next, to determine the target of C-PC at receptor level, we explored whether TLR4 could be required for the proinflammatory effect of C-PC. First, we examined the extracellular region of the receptor complex composed of TLR4 and myeloid differentiation protein 2 (MD-2). To this end, microglia were treated with curcumin, ciprofloxacin, or L48H37, three TLR4 inhibitors that interfere with LPS binding to MD-2 [42-45]. Curcumin (10 $\mu \mathrm{M})$, ciprofloxacin $(100 \mu \mathrm{g} / \mathrm{mL})$, and L48H37 (1-ethyl-3,5-bis(3,4,5-trimethoxybenzylidene)piperidin-4-one; $10 \mu \mathrm{M}$ ) reduced the release of IL-1 $\beta$ and TNF- $\alpha$ by microglia stimulated with LPS (used as positive control; Figure 6, gray bars) and C-PC (Figure 6, light red bars). Specifically, the three inhibitors had effects on cytokine release after C-PC stimulation similar to those observed after LPS treatment, suggesting that TLR4 could be the target of the proinflammatory activity of C-PC.

A

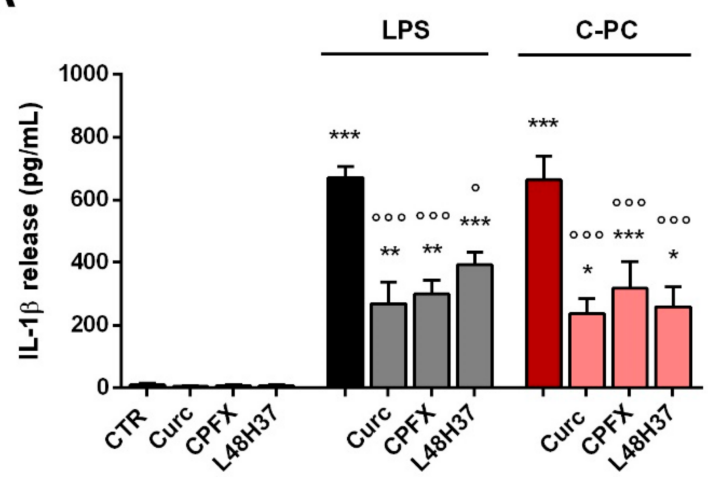

B

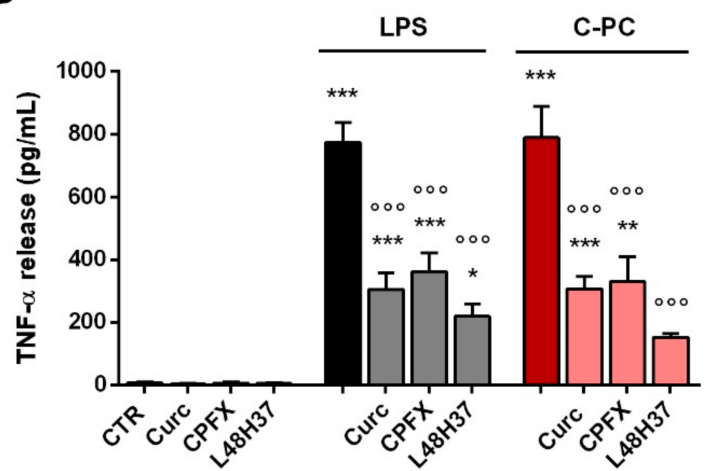

Figure 6. Effect of Toll-like receptor 4 inhibition on cytokine release from cortical microglia. Microglia were cultured overnight in medium containing $10 \%$ of serum, which was replaced with serum-free medium before pretreatment with curcumin (Curc, $10 \mu \mathrm{M})$, ciprofloxacin (CPFX, $100 \mu \mathrm{g} / \mathrm{mL}$ ), or L48H37 $(10 \mu \mathrm{M})$ for $1 \mathrm{~h}$ followed by stimulation with LPS $(100 \mathrm{ng} / \mathrm{mL})$ or C-PC $(100 \mu \mathrm{g} / \mathrm{mL})$ for $16 \mathrm{~h}$. Supernatant were collected and analyzed for IL-1 $\beta(\mathbf{A})$ and TNF- $\alpha(\mathbf{B})$ content. Data are means \pm SEM $\left(n=3\right.$ in triplicate). ${ }^{*} p<0.05,{ }^{* *} p<0.01$, and ${ }^{* * *} p<0.001$ versus control cells. ${ }^{\circ} p<0.05$ and

${ }_{0 \circ 0} p<0.001$ versus LPS or C-PC treatment. One-way ANOVA followed by Holm-Sidak's test. 
Further, we analyzed the role of TLR4 in mediating the effects of C-PC using CLI-095, a cyclohexene derivative that selectively inhibits TLR4 signaling mediated by the receptor intracellular domain [46-48]. CLI-095 $(0.5 \mu \mathrm{g} / \mathrm{mL})$ completely reduced the release of IL-1 $\beta$ and TNF- $\alpha$ by microglia stimulated with LPS (Figure 7, gray bars) and C-PC (Figure 7, light red bars), confirming that TLR4 is involved in the inflammatory effect of C-PC.

A

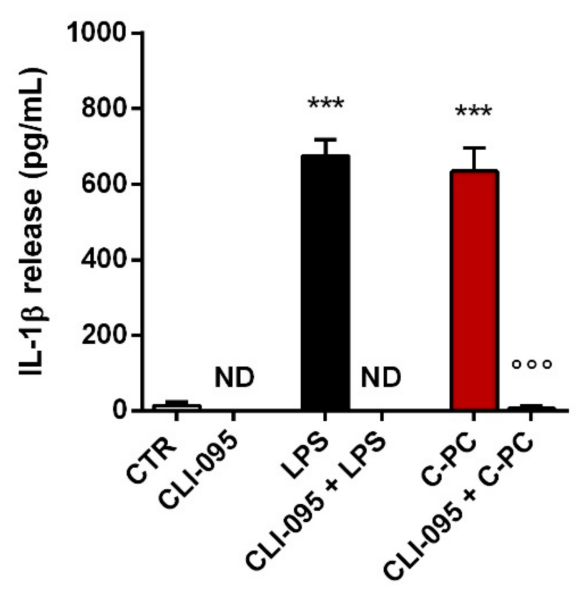

B

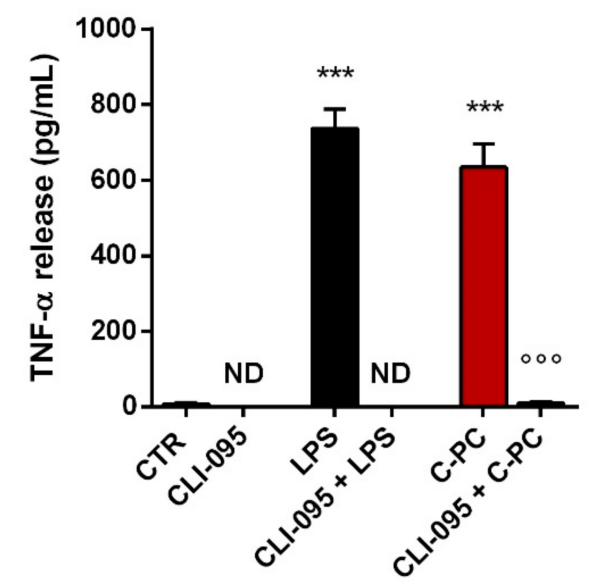

Figure 7. Effect of CLI-095 on cytokine release from cortical microglia. Microglia were cultured overnight in medium containing $10 \%$ of serum, which was replaced with serum-free medium before pretreatment with $0.5 \mu \mathrm{g} / \mathrm{mL}$ CLI-095 for $1 \mathrm{~h}$ followed by stimulation with LPS $(100 \mathrm{ng} / \mathrm{mL})$ or C-PC $(100 \mu \mathrm{g} / \mathrm{mL})$ for $16 \mathrm{~h}$. Supernatant were collected and analyzed for IL-1 $\beta$ (A) and TNF- $\alpha$ (B) content. Data are means \pm SEM ( $n=3$ in triplicate). ${ }^{* * *} p<0.001$ versus control cells and ${ }^{\circ 00} p<0.001$ versus C-PC treatment. One-way ANOVA followed by Holm-Sidak's test. ND, not determined.

\section{Discussion}

We have recently shown that an acetone extract from the microalga Spirulina platensis reduced the release of proinflammatory cytokines and impeded LPS-triggered neuroinflammation in microglial cells. The studied extract contained chlorophylls, pheophytins and carotenoids that could be implicated in the anti-inflammatory effect observed [14]. Indeed chlorophylls, pheophytins, and carotenoids have been shown to exhibit promising antiinflammatory activities in numerous experimental models [49-51]. Spirulina platensis also synthetizes C-PC, a water-soluble pigment, known worldwide as a food additive and cosmetic colorant with potential biological activities and health benefits [52]. Antioxidant and antitumor activities, together with hepatic, renal, cardiovascular, and CNS protective properties of C-PC from Spirulina platensis have been extensively shown [19-25,53-58]. Moreover, it should be emphasized that Spirulina and C-PC, in particular, exert anti-inflammatory and immunomodulatory activities by stimulating the production of antibodies and up- or down-regulating the expression of different sets of key cytokines, such as IL-1 $\beta$, IL-2, IL-4, IL-6, IL-10, and TNF- $\alpha$ [10-14,59].

In the present study we examined the effect of C-PC in the inflammatory phenotype of microglia, the primary innate immune cells of the CNS. Noncytotoxic concentrations of CPC increased the expression and release of the proinflammatory cytokines IL- $1 \beta$ and TNF- $\alpha$ under basal conditions (i.e., in the absence of an inflammatory stimulus). In addition, C-PC induced translocation to the nucleus of the NF- $\mathrm{kB} / \mathrm{p} 65$ subunit, indicating the activation of NF- $\mathrm{BB}$ signaling, widely implicated in immune responses. These results suggest that C-PC, similarly to LPS, drives microglia into a proinflammatory phenotype, which is characterized by the production of proinflammatory mediators including IL-1 $\beta$, IL-6, TNF$\alpha$, nitric oxide, and reactive oxygen radicals as well as by an increased expression of surface markers such as CD16/32, CD40, CD86, which sustain the inflammatory process $[29,60]$. Our findings confirm those of Chen et al. [24] that purified C-PC from Spirulina and showed its capability to induce the expression of IL-6, proIL- $1 \beta$, IL- $1 \beta$, TNF- $\alpha$, COX-2 
and the phosphorylation of ERK, JNK, p38, and IKB in the murine macrophage cell line J774A.1. However, our results differ from other numerous studies that revealed the antiinflammatory effect of C-PC in various cell types [19,22,23,57,58], including BV-2 microglial cells. In particular, Chen et al. [23] showed that C-PC prevented the up-regulation of IL-6, TNF- $\alpha$, iNOS, and COX-2 induced by LPS in BV-2 microglia cells, suggesting that C-PC may contribute to neuroprotection in degenerative disorders in which microglial activation plays a detrimental role. This inconsistency may be partly caused by the difference between primary microglia, used in our study, and the BV-2 cell line. Despite the similarity of BV-2 cells to primary microglia, their use as an alternative model to primary microglia has long been debated. The main idea is that BV-2 cells have almost identical functions as primary microglia, but not to the same extent. For example, upon LPS stimulation, many of the genes induced by BV-2 cells are also up-regulated in primary microglia; however, they are more pronounced in primary microglia compared to the BV-2 cell line [61,62].

C-PC used in this study was extracted and purified from Spirulina that belongs to the cyanobacteria group. Cyanobacteria are prokaryotes that contain the basic structure and chemical composition of the cell wall of Gram-negative bacteria, while similarly to eukaryotes they possess a photosynthesis apparatus. Cyanobacterial cell wall contains LPS in the outer membrane layer and LPS comprises $1.6 \%$ of the cellular dry weight of Spirulina [63]. For that reason, firstly we verified the presence of LPS in the C-PC preparation used. To this aim, microglia were treated with $\mathrm{PMB}$, a cyclic cationic polypeptide antibiotic produced by Bacillus polymixa, that binds and neutralizes LPS of the outer cell membrane of Gram-negative bacteria [64]. PMB did not affect the C-PC-induced microglia inflammatory response, proving that C-PC preparation used in this study was free from LPS contamination and, most important, supporting the direct immunomodulatory effect of C-PC in microglia.

Although C-PC has been widely studied, signaling pathways involved in its biological effects are largely unclear. Thus, here we tried to delineate the target for the immunomodulatory effect of C-PC. Immune response, including that of microglia, initiates with the activation of several classes of pattern recognition receptors, including TLRs. Among them, TLR4 associated with MD-2 is responsible for the initiation of rapid innate immune responses. Binding of ligands, such as LPS, causes dimerization of the extracellular domains and the subsequent recruitment of specific adaptor proteins to the intracellular domains, thus initiating a signaling cascade $[32,65]$. Previous studies have proposed that inflammatory cascade can be prevented by compounds able to bind to TLR4-MD-2 complex and inhibit its dimerization, required for the activation of downstream signaling pathways [66]. In this context, previous studies, including ours, have shown that curcumin, the major active compound of turmeric, binds directly to the MD-2 pocket, competing with LPS for the same binding site and resulting in the suppression of LPS-induced proinflammatory signaling [42,43]. We also showed that ciprofloxacin, a commonly prescribed antibiotic, can accommodate into the binding pocket of MD-2 occupying a relevant portion of the LPS binding site through the same mechanism of curcumin [44]. Moreover, among the curcumin structural analogues, $\mathrm{L} 48 \mathrm{H} 37$ exerts a strong anti-inflammatory activity by targeting MD-2 and inhibiting the formation of TLR4-MD-2-LPS complex [45]. Based on these findings, to explore whether C-PC may target TLR4-MD-2, the receptor complex has been inhibited with curcumin, ciprofloxacin, or L48H37. When microglia were treated with the compounds before stimulation with C-PC, cells showed a suppressed release of IL-1 $\beta$ and TNF- $\alpha$, suggesting the engagement of TLR4-MD-2 complex in mediating the effect of C-PC. To further support the role of this receptor in mediating the effect of C-PC, microglia were also treated with CLI-095 (also known as TAK-242), a TLR4-specific inhibitor that inhibits TLR4 signaling by binding directly to the intracellular TIR domain of TLR4 [46-48]. In our experimental conditions, CLI-095 completely abolished the C-PC-induced release of IL-1 $\beta$ and TNF- $\alpha$, confirming the role of TLR4 in mediating microglia immune response induced by C-PC. Furthermore, considering that CLI-095 completely blocked the release of both cytokines, the effect of C-PC appears exclusively mediated by TLR4-MD-2 complex. 
Even if the binding mode as well as the precise binding site of C-PC on TLR4-MD2 complex remain to be define, this study helped to clarify the mechanism underlying immunomodulatory activity of C-PC, showing for the first time, to our knowledge, that the signaling through TLR4 can be critically involved. Furthermore, it is noteworthy that in vivo, after oral administration, C-PC is degraded by proteolysis to phycocyanobilin, the linear tetrapyrrole chromophore of C-PC, or to phycocyanobilin-linked peptides [67]. Phycocyanobilin, in particular, possesses anticancer, anti-inflammatory, atheroprotective, nephroprotective, and neuroprotective effects [68-73], suggesting that most of the pharmacological actions of C-PC could be ascribed to phycocyanobilin. Therefore, additional in vivo studies will be relevant to definitively prove the functional role of TLR4 in C-PC immunomodulatory effect and to clarify whether phycocyanobilin could contribute to this effect.

\section{Materials and methods}

\subsection{Reagents}

All reagents were from Sigma-Aldrich (Milan, Italy), unless noted otherwise. Tissue culture media, fetal bovine serum (FBS), and antibiotics were purchased from Life Technologies (San Giuliano Milanese, Italy). LPS (Ultra-Pure LPS-EB from Escherichia coli, 0111:B4 strain that only activates TLR4) and (6R)-6-[N-(2-chloro-4-fluorophenyl)sulfamoyl]cyclohex-1-ene1-carboxylate (CLI-095 or TAK-242) were from InvivoGen (InvivoGen Europe, Toulouse, France). C-PC was purchased from Sigma-Aldrich as a lyophilized powder obtained from Spirulina platensis with a 30-50\% of protein content and the $\mathrm{PC}$ ratios $\left(\mathrm{A}_{620} / \mathrm{A}_{280}\right)>3.5$ [24]. The primary antibody mouse anti-p65 (NF-kB p65, Cat. sc-8008) was from Santa Cruz Biotechnology (Santa Cruz, CA, USA). Alexa Fluor 555 secondary antibody was from Invitrogen (Milan, Italy, Cat. A21422). Enzyme-linked immunosorbent assay (ELISA) kits were obtained from Antigenix America (Huntington Station, NY, USA). Falcon tissue culture plasticwares were purchased from BD Biosciences (SACCO srl, Cadorago (CO), Italy).

\subsection{Cell Cultures}

All experimental procedures were conducted according to national and EU guidelines for animal experiments and were approved by the Institutional Review Board for Animal Research (Organismo Preposto al Benessere Animale, OPBA) of the University of Padua and by the Italian Ministry of Health (protocol number 41451.N.N8P). Microglial cells were isolated from mixed glial cell cultures prepared from cerebral cortices of postnatal day 1 Sprague-Dawley rat pups (CD strain), as previously described [74]. Typically, 7 days after isolation, cultures reached confluence and microglia were recovered by shaking the flasks (200 rpm for $1 \mathrm{~h}$ at $37^{\circ} \mathrm{C}$ ), resuspended in high-glucose Dulbecco's modified eagle medium (DMEM) supplemented with $2 \mathrm{mM}$ L-glutamine, $10 \%$ heat-inactivated FBS, 100 units $/ \mathrm{mL}$ penicillin, $100 \mu \mathrm{g} / \mathrm{mL}$ streptomycin and $50 \mu \mathrm{g} / \mathrm{mL}$ gentamicin (growth medium), and plated on poly-L-lysine-coated $(10 \mu \mathrm{g} / \mathrm{mL})$ plastic wells at a density of $1.50 \times 10^{5}$ cells $/ \mathrm{cm}^{2}$. Cells were allowed to adhere for $45 \mathrm{~min}$ and then washed to remove nonadhering cells. The procedure used generated microglial cultures of $97 \%$ purity, as determined by immunocytochemistry using a primary antibody against ionized calcium binding adaptor molecule 1 (Iba1, 1:800, Wako Chemicals USA Inc., Richmond, VA, USA, Cat. 019-19741), a marker for microglia cell types. Cells were maintained at $37^{\circ} \mathrm{C}$ in a humidified atmosphere containing $5 \% \mathrm{CO}_{2} / 95 \%$ air.

\subsection{Cell Viability}

The sulforhodamine B (SRB) assay was used to measure microglial cell viability $[75,76]$. Cells were plated in poly-L-lysine coated 96-well plates (50,000 cells/well) in growth medium containing $10 \%$ of serum and allowed to adhere overnight. Growth medium was replaced with serum-free medium $2 \mathrm{~h}$ before treatment with increasing concentrations of C-PC for $16 \mathrm{~h}$. At the end of incubation, cells were fixed with cold $10 \%$ trichloroacetic acid for $1 \mathrm{~h}$ at $4{ }^{\circ} \mathrm{C}$. Then, cells were stained with $0.4 \% \mathrm{SRB}$ for $30 \mathrm{~min}$ at room temperature. 
Following this step, the protein-bound dye was solubilized with $10 \mathrm{mM}$ Tris base solution. The absorbance was then measured at $570 \mathrm{~nm}$ in a microplate reader. Absorbance of vehicle-treated cultures was considered as $100 \%$ cell viability.

\subsection{Cytokine Determination}

After the exposure to LPS or C-PC for $16 \mathrm{~h}$, cell supernatants were collected and the content of IL-1 $\beta$ and TNF- $\alpha$ measured using commercially available ELISA kits, according to the manufacturer's instructions (Antigenix America, Huntington Station, NY, USA). The absolute concentration of cytokines $(\mathrm{pg} / \mathrm{mL})$ in the culture medium was calculated from standard curves obtained with known amounts of IL-1 $\beta$ or TNF- $\alpha$.

\subsection{Real-Time Polymerase Chain Reaction (Real-Time PCR)}

After the exposure to LPS or C-PC for $6 \mathrm{~h}$, total RNA was extracted from cells by QIAzol (Invitrogen), according to the manufacturer's instructions. The amount and purity of RNA extracted were assessed by RNA 6000 Nano assay in an Agilent BioAnalyser (Thermo Scientific, Milan, Italy). Reverse transcription was performed with SuperScript IV reverse transcriptase (Thermo Fisher Scientific, Milan, Italy). The real-time PCR reaction was performed as described previously [77]. Primers were selected using the NCBI primer designing tool (Primer-Blast), constraining the choice to specific amplification of only one target amplicon for each gene mRNA and to the absence of primer dimers and secondary structures. Primer sequences were: $\beta$-actin, $5^{\prime}$-GATCAGCAAGCAGGAGTACGATGA-3'; 5'-GGTGTAAAACGCAGCTCAGTAACA-3'; IL-1 $\beta$, 5'-CGTCCTCTGTGACTCGTGGG-3'; $5^{\prime}$-ATGGGTCAGACAGCACGAGG-3'; TNF- $\alpha$, 5'-GCAGGTTCCGTCCCTCTCAT- ${ }^{\prime} ; 5^{\prime}$ TGCCAGTTCCACATCTCGGA-3'. Amounts of amplified product were calculated using linear regression analysis from standard curves, demonstrating amplification efficiencies ranging from 95 to $100 \%$. Dissociation curves were generated for each primer pair, showing single-product amplification. Data were normalized to expression levels of the reference gene $\beta$-actin and are presented as specific ratio between the gene of interest and $\beta$-actin.

\subsection{Immunofluorescence}

Microglia, grown on coverslips in 24-well plates, were treated for 90 min with $100 \mu \mathrm{g} / \mathrm{mL}$ C-PC, $100 \mathrm{ng} / \mathrm{mL}$ LPS, or their association for the analysis of NF- $\mathrm{BB}$ activation. Cells were fixed with $4 \%$ paraformaldehyde ( $\mathrm{pH} \mathrm{7.4)} \mathrm{for} 15 \mathrm{~min}$ at room temperature. After blocking nonspecific binding sites with 5\% normal goat serum/0.1\% Triton X-100 in PBS (blocking solution) for $1 \mathrm{~h}$ at room temperature, cells were incubated with the primary antibody antip65 (NF-kB p65, 1:500) for $2 \mathrm{~h}$ at room temperature. Then, cells were extensively washed with PBS and incubated with the Alexa Fluor 555 secondary antibody (1:1000) for $1 \mathrm{~h}$ at room temperature. Both antibodies were diluted in the blocking solution. Negative control omitted the primary antibody. Nuclei were stained with 4,6-diamidino-2-phenylindole (DAPI; $0.1 \mu \mathrm{g} / \mathrm{mL}$ ) and coverslips were mounted on microscope slides with Fluoromount-G mounting medium (Fisher Scientific, Milan, Italy) [44]. All images were acquired using a confocal laser-scanning microscope (Zeiss LSM 800; Carl Zeiss AG, Germany). Acquisition settings were kept constant to permit a direct comparison of all images.

\subsection{Statistical Analysis}

Results are given as mean \pm SEM. Data were analyzed using GraphPad Prism Software, version 6.0 (GraphPad Software, Inc., San Diego, CA, USA). Statistical analyses were performed by one-way analysis of variance (ANOVA) followed by Holm-Sidak's post hoc test for multiple comparison. Statistically significant differences were taken at $p<0.05$.

Author Contributions: Conceptualization, A.P., R.F., P.G. and M.Z.; methodology, C.A.; formal analysis, A.P., R.F., S.M., P.G. and M.Z.; data curation, A.P. and M.Z; writing-original draft preparation, P.G. and M.Z; writing-review and editing, A.P., R.F., S.M., P.G. and M.Z.; funding acquisition, A.P., R.F. and M.Z. All authors have read and agreed to the published version of the manuscript. 
Funding: This research was supported by grants from the University of Padua, Italy (UNIPD-DSFDOR-2019 and 2020 founds to A.P., R.F. and M.Z.).

Institutional Review Board Statement: The study was conducted according to the guidelines of the Declaration of Helsinki and approved by the Institutional Review Board of the University of Padua and by the Italian Ministry of Health (protocol number 41451.N.N8P; 11 November 2019).

Informed Consent Statement: Not applicable.

Data Availability Statement: The data presented in this study are available on request from the corresponding author.

Acknowledgments: We thank Massimo Rizza for technical assistance in animal handling and Andrea Pagetta for technical assistance on confocal microscopy.

Conflicts of Interest: The authors declare no conflict of interest.

\section{References}

1. Safi, C.; Ursu, A.V.; Laroche, C.; Zebib, B.; Merah, O.; Pontalier, P.Y.; Vaca-Garcia, C. Aqueous extraction of proteins from microalgae: Effect of different cell disruption methods. Algal Res. 2014, 3, 61-65. [CrossRef]

2. Kulshreshtha, A.; Zacharia, A.J.; Jarouliya, U.; Bhadauriya, P.; Prasad, G.B.; Bisen, P.S. Spirulina in health care management. Curr Pharm. Biotechnol. 2008, 9, 400-405. [CrossRef] [PubMed]

3. Banji, D.; Banji, O.J.; Pratusha, N.G.; Annamalai, A.R. Investigation on the role of Spirulina platensis in ameliorating behavioural changes, thyroid dysfunction and oxidative stress in offspring of pregnant rats exposed to fluoride. Food Chem. 2013, 140, 321-331. [CrossRef] [PubMed]

4. Abdelkhalek, N.K.; Ghazy, E.W.; Abdel-Daim, M.M. Pharmacodynamic interaction of Spirulina platensis and deltamethrin in freshwater fish Nile tilapia, Oreochromis niloticus: Impact on lipid peroxidation and oxidative stress. Environ. Sci. Pollut. Res. Int. 2015, 22, 3023-3031. [CrossRef] [PubMed]

5. Abdel-Daim, M.M.; Abuzead, S.M.; Halawa, S.M. Protective role of Spirulina platensis against acute deltamethrin-induced toxicity in rats. PLoS ONE 2013, 8, e72991. [CrossRef]

6. Upasani, C.D.; Balaraman, R. Protective effect of Spirulina on lead induced deleterious changes in the lipid peroxidation and endogenous antioxidants in rats. Phytother. Res. 2003, 17, 330-334. [CrossRef]

7. Wu, L.C.; Ho, J.A.; Shieh, M.C.; Lu, I.W. Antioxidant and antiproliferative activities of Spirulina and Chlorella water extracts. J. Agric. Food Chem. 2005, 53, 4207-4212. [CrossRef]

8. Deng, R.; Chow, T.J. Hypolipidemic, antioxidant and anti-inflammatory activities of microalgae spirulina. Cardiovasc. Ther. 2010, 28, e33-e45. [CrossRef]

9. Khalil, S.R.; Salem, H.F.A.; Metwally, M.M.M.; Emad, R.M.; Elbohi, K.M.; Ali, S.A. Protective effect of Spirulina platensis against physiological, ultrastructural and cell proliferation damage induced by furan in kidney and liver of rat. Ecotoxicol. Environ. Saf. 2020, 192, 110256. [CrossRef]

10. Mao, T.K.; VAN DE Water, J.; Gershwin, M.E. Effect of spirulina on the secretion of cytokines from peripheral blood mononuclear cells. J. Med. Food. 2000, 3, 135-140. [CrossRef]

11. Khan, Z.; Bhadouria, P.; Bisen, P.S. Nutritional and therapeutic potential of Spirulina. Curr. Pharm. Biotechnol. 2005, 6, 373-379. [CrossRef] [PubMed]

12. Aladaileh, S.H.; Khafaga, A.F.; Abd El-Hack, M.E.; Al-Gabri, N.A.; Abukhalil, M.H.; Alfwuaires, M.A.; Bin-Jumah, M.; Alkahtani, S.; Abdel-Daim, M.M.; Aleya, L.; et al. Spirulina platensis ameliorates the sub chronic toxicities of lead in rabbits via anti-oxidative, anti-inflammatory, and immune stimulatory properties. Sci. Total Environ. 2020, 701, 34879. [CrossRef] [PubMed]

13. Pham, T.X.; Park, Y.K.; Lee, J.Y. Anti-inflammatory effects of Spirulina platensis extract via the modulation of histone deacetylases. Nutrients. 2016, 8, 381. [CrossRef]

14. Piovan, A.; Battaglia, J.; Filippini, R.; Dalla Costa, V.; Facci, L.; Argentini, C.; Pagetta, A.; Giusti, P.; Zusso, M. Pre- and early post-treatment with Arthrospira platensis (Spirulina) extract impedes lipopolysaccharide-triggered neuroinflammation in microglia. Front. Pharmacol. 2021, 12, 724993. [CrossRef] [PubMed]

15. Schafer, F.Q.; Wang, H.P.; Kelley, E.E.; Cueno, K.L.; Martin, S.M.; Buettner, G.R. Comparing beta-carotene, vitamin E and nitric oxide as membrane antioxidants. Biol. Chem. 2002, 383, 671-681. [CrossRef] [PubMed]

16. Bermejo, P.; Piñero, E.; Villar, Á.M. Iron-chelating ability and antioxidant properties of phycocyanin isolated from a protean extract of Spirulina platensis. Food Chem. 2008, 110, 436-445. [CrossRef]

17. Silva, S.C.; Ferreira, I.C.F.R.; Dias, M.M.; Barreiro, M.F. Microalgae-derived pigments: A 10-year bibliometric review and industry and market trend analysis. Molecules. 2020, 25, 3406. [CrossRef]

18. Prasanna, R.; Sood, A.; Suresh, A.; Nayak, S.; Kaushik, B.D. Potentials and applications of algal pigments in biology and industry. Acta Botanica Hungarica. 2007, 49, 131-156. [CrossRef]

19. Romay, C.H.; González, R.; Ledón, N.; Remirez, D.; Rimbau, V. C-phycocyanin: A biliprotein with antioxidant, anti-inflammatory and neuroprotective effects. Curr. Protein Pept. Sci. 2003, 4, 207-216. [CrossRef] 
20. Pleonsil, P.; Soogarun, S.; Suwanwong, Y. Anti-oxidant activity of holo- and apo-c-phycocyanin and their protective effects on human erythrocytes. Int. J. Biol. Macromol. 2013, 60, 393-398. [CrossRef]

21. Pentón-Rol, G.; Marín-Prida, J.; Falcón-Cama, V. C-Phycocyanin and phycocyanobilin as remyelination therapies for enhancing recovery in multiple sclerosis and ischemic stroke: A preclinical perspective. Behav. Sci. 2018, 8, 15. [CrossRef] [PubMed]

22. Cherng, S.C.; Cheng, S.N.; Tarn, A.; Chou, T.C. Anti-inflammatory activity of c-phycocyanin in lipopolysaccharide-stimulated RAW 264.7 macrophages. Life Sci. 2007, 81, 1431-1435 doiorg/101016/jlfs200709009. [CrossRef] [PubMed]

23. Chen, J.C.; Liu, K.S.; Yang, T.J.; Hwang, J.H.; Chan, Y.C.; Lee, I.T. Spirulina and C-phycocyanin reduce cytotoxicity and inflammation-related genes expression of microglial cells. Nutr. Neurosci. 2012, 15, 252-256. [CrossRef] [PubMed]

24. Chen, W.-W.; Yang, T.-S.; Chen, M.-J.; Chang, Y.-C.; Wang, E.I.-C.; Ho, C.-L.; Lai, Y.-J.; Yu, C.-C.; Chou, J.-C.; Chao, L.K.-P.; et al. Purification and immunomodulating activity of C-phycocyanin from Spirulina platensis cultured using power plant flue gas. Process Biochem. 2014, 49, 1337-1344. [CrossRef]

25. Rimbau, V.; Camins, A.; Romay, C.; González, R.; Pallàs, M. Protective effects of C-phycocyanin against kainic acid-induced neuronal damage in rat hippocampus. Neurosci. Lett. 1999, 276, 75-78. [CrossRef]

26. Pentón-Rol, G.; Marín-Prida, J.; Pardo-Andreu, G.; Martínez-Sánchez, G.; Acosta-Medina, E.F.; Valdivia-Acosta, A.; LagumersindezDenis, N.; Rodríguez-Jiménez, E.; Llópiz-Arzuaga, A.; López-Saura, P.A.; et al. C-Phycocyanin is neuroprotective against global cerebral ischemia/reperfusion injury in gerbils. Brain Res. Bull. 2011, 86, 42-52 doiorg/101016/jbrainresbull201105016. [CrossRef]

27. Bordt, E.A.; Polster, B.M. NADPH oxidase- and mitochondria-derived reactive oxygen species in proinflammatory microglial activation: A bipartisan affair? Free Radic. Biol. Med. 2014, 76, 34-46. [CrossRef]

28. Ransohoff, R.M. A polarizing question: Do M1 and M2 microglia exist? Nat. Neurosci. 2016, 19, 987-991. [CrossRef]

29. Tang, Y.; Le, W. Differential roles of M1 and M2 microglia in neurodegenerative diseases. Mol. Neurobiol. 2016, 53, 1181-1194. [CrossRef]

30. Masuda, T.; Sankowski, R.; Staszewski, O.; Prinz, M. Microglia Heterogeneity in the Single-Cell Era. Cell Rep. 2020, 30, $1271-1281$. [CrossRef]

31. Graeber, M.B. Changing face of microglia. Science 2010, 330, 783-788. [CrossRef] [PubMed]

32. Davis, M.J.; Tsang, T.M.; Qiu, Y.; Dayrit, J.K.; Freij, J.B.; Huffnagle, G.B.; Olszewski, M.A. Macrophage M1/M2 polarization dynamically adapts to changes in cytokine microenvironments in Cryptococcus neoformans infection. MBio 2013, 4, e00264-13. [CrossRef] [PubMed]

33. Kawai, T.; Akira, S. The role of pattern-recognition receptors in innate immunity: Update on toll-like receptors. Nat. Immunol. 2010, 11, 373-384. [CrossRef] [PubMed]

34. Garaude, J.; Kent, A.; van Rooijen, N.; Blander, J.M. Simultaneous targeting of toll- and nod-like receptors induces effective tumor-specific immune responses. Sci. Transl. Med. 2012, 4, 120ra16. [CrossRef] [PubMed]

35. Park, B.S.; Song, D.H.; Kim, H.M.; Choi, B.S.; Lee, H.; Lee, J.O. The structural basis of lipopolysaccharide recognition by the TLR4-MD-2 complex. Nature 2009, 458, 1191-1195. [CrossRef] [PubMed]

36. Akira, S.; Takeda, K. Toll-like receptor signalling. Nat. Rev. Immunol. 2004, 4, 499-511. [CrossRef] [PubMed]

37. Kumar, H.; Kawai, T.; Akira, S. Toll-like receptors and innate immunity. Biochem. Biophys. Res. Commun. 2009, 388, 621-625. [CrossRef]

38. Gupta, S.C.; Kim, J.H.; Prasad, S.; Aggarwal, B.B. Regulation of survival, proliferation, invasion, angiogenesis, and metastasis of tumor cells through modulation of inflammatory pathways by nutraceuticals. Cancer Metastasis Rev. 2010, 29, 405-434. [CrossRef]

39. Liu, T.; Zhang, L.; Joo, D.; Sun, S.C. NF-кB signaling in inflammation. Signal. Transduct. Target Ther. 2017, 2, 17023. [CrossRef]

40. Tsuzuki, H.; Tani, T.; Ueyama, H.; Kodama, M. Lipopolysaccharide: Neutralization by polymyxin B shuts down the signaling pathway of nuclear factor $\mathrm{\kappa B}$ in peripheral blood mononuclear cells, even during activation. J. Surg. Res. 2001, 100, 127-134. [CrossRef]

41. Cheng, Y.; Du, J.; Han, J.; Sun, W.; Gao, F.; Zhang, P.; Zhao, H.; Chen, M.; Wang, J.; Wang, M.; et al. Polymyxin B attenuates LPS-induced death but aggravates radiation-induced death via TLR4-Myd88-IL-6 pathway. Cell. Physiol. Biochem. 2017, 42, 1120-1126. [CrossRef] [PubMed]

42. Gradisar, H.; Keber, M.M.; Pristovsek, P.; Jerala, R. MD-2 as the target of curcumin in the inhibition of response to LPS. J. Leukoc. Biol. 2007, 82, 968-974. [CrossRef] [PubMed]

43. Zusso, M.; Mercanti, G.; Belluti, F.; Di Martino, R.M.C.; Pagetta, A.; Marinelli, C.; Brun, P.; Ragazzi, E.; Lo, R.; Stifani, S.; et al Phenolic 1,3-diketones attenuate lipopolysaccharide-induced inflammatory response by an alternative magnesium-mediated mechanism. Br. J. Pharmacol. 2017, 174, 1090-1103. [CrossRef] [PubMed]

44. Zusso, M.; Lunardi, V.; Franceschini, D.; Pagetta, A.; Lo, R.; Stifani, S.; Frigo, A.C.; Giusti, P.; Moro, S. Ciprofloxacin and levofloxacin attenuate microglia inflammatory response via TLR4/NF-kB pathway. J. Neuroinflammation 2019, 16, 148. [CrossRef]

45. Wang, Y.; Shan, X.; Dai, Y.; Jiang, L.; Chen, G.; Zhang, Y.; Wang, Z.; Dong, L.; Wu, J.; Guo, G.; et al. Curcumin analog L48H37 prevents lipopolysaccharide-induced TLR4 signaling pathway activation and sepsis via targeting MD2. J. Pharmacol. Exp. Ther. 2015, 353, 539-550. [CrossRef]

46. Li, M.; Matsunaga, N.; Hazeki, K.; Nakamura, K.; Takashima, K.; Seya, T.; Hazeki, O.; Kitazaki, T.; Iizawa, Y. A novel cyclohexene derivative, ethyl (6R)-6-[N-(2-Chloro-4-fluorophenyl)sulfamoyl]cyclohex-1-ene-1-carboxylate (TAK-242), selectively inhibits toll-like receptor 4-mediated cytokine production through suppression of intracellular signaling. Mol. Pharmacol. 2006, 69, 1288-1295. [CrossRef] 
47. Kawamoto, T.; Ii, M.; Kitazaki, T.; Iizawa, Y.; Kimura, H. TAK-242 selectively suppresses Toll-like receptor 4-signaling mediated by the intracellular domain. Eur. J. Pharmacol. 2008, 584, 40-48. [CrossRef]

48. Takashima, K.; Matsunaga, N.; Yoshimatsu, M.; Hazeki, K.; Kaisho, T.; Uekata, M.; Hazeki, O.; Akira, S.; Iizawa, Y.; Ii, M. Analysis of binding site for the novel small-molecule TLR4 signal transduction inhibitor TAK-242 and its therapeutic effect on mouse sepsis model. Br. J. Pharmacol. 2009, 157, 1250-1262. [CrossRef]

49. Subramoniam, A.; Asha, V.V.; Nair, S.A.; Sasidharan, S.P.; Sureshkumar, P.K.; Rajendran, K.N.; Karunagaran, D.; Ramalingam, K. Chlorophyll revisited: Anti-inflammatory activities of chlorophyll a and inhibition of expression of TNF- $\alpha$ gene by the same. Inflammation 2012, 35, 959-966 doiorg/101007/s10753. [CrossRef]

50. Li, R.; Hong, P.; Zheng, X. $\beta$-carotene attenuates lipopolysaccharide-induced inflammation via inhibition of the NF- $\mathrm{kB}$, JAK2/STAT3 and JNK/p38 MAPK signaling pathways in macrophages. Anim. Sci. J. 2019, 90, 140-148. [CrossRef]

51. Carvalho, A.M.S.; Heimfarth, L.; Pereira, E.W.M.; Oliveira, F.S.; Menezes, I.R.A.; Coutinho, H.D.M.; Picot, L.; Antoniolli, A.R.; Quintans, J.S.S.; Quintans-Júnior, L.J. Phytol, a chlorophyll component, produces antihyperalgesic, anti-inflammatory, and antiarthritic effects: Possible NFKB pathway involvement and reduced levels of the proinflammatory cytokines TNF- $\alpha$ and IL-6. $J$. Nat. Prod. 2020, 83, 1107-1117. [CrossRef] [PubMed]

52. Liu, Q.; Huang, Y.; Zhang, R.; Cai, T.; Cai, Y. Medical application of Spirulina platensis derived C-phycocyanin. Evid. Based Complement. Alternat. Med. 2016, 2016, 7803846. [CrossRef] [PubMed]

53. Cian, R.E.; López-Posadas, R.; Drago, S.R.; de Medina, F.S.; Martínez-Augustin, O. Immunomodulatory properties of the protein fraction from Phorphyra columbina. J. Agric. Food Chem. 2012, 60, 8146-8154. [CrossRef] [PubMed]

54. Sheu, M.J.; Hsieh, Y.Y.; Lai, C.H.; Chang, C.C.; Wu, C.H. Antihyperlipidemic and antioxidant effects of C-phycocyanin in golden Syrian hamsters fed with a hypercholesterolemic diet. J. Tradit. Complement Med. 2013, 3, 41-47. [CrossRef]

55. Hussein, M.M.; Ali, H.A.; Ahmed, M.M. Ameliorative effects of phycocyanin against gibberellic acid induced hepatotoxicity. Pestic. Biochem. Physiol. 2015, 119, 28-32. [CrossRef]

56. Saini, M.K.; Sanyal, S.N. Cell cycle regulation and apoptotic cell death in experimental colon carcinogenesis: Intervening with cyclooxygenase-2 inhibitors. Nutr. Cancer 2015, 67, 620-636. [CrossRef]

57. Remirez, D.; González, R.; Merino, N.; Rodriguez, S.; Ancheta, O. Inhibitory effects of Spirulina in zymosan-induced arthritis in mice. Mediators Inflamm. 2002, 11, 75-79. [CrossRef]

58. Martinez, S.E.; Chen, Y.; Ho, E.A.; Martinez, S.A.; Davies, N.M. Pharmacological effects of a C-phycocyanin-based multicomponent nutraceutical in an in-vitro canine chondrocyte model of osteoarthritis. Can. J. Vet. Res. 2015, 79, 241-249.

59. Wu, Q.; Liu, L.; Miron, A.; Klímová, B.; Wan, D.; Kuča, K. The antioxidant, immunomodulatory, and anti-inflammatory activities of Spirulina: An overview. Arch. Toxicol. 2016, 90, 1817-1840. [CrossRef]

60. Jurga, A.M.; Paleczna, M.; Kuter, K.Z. Overview of general and discriminating markers of differential microglia phenotypes Front. Cell. Neurosci. 2020, 14, 198. [CrossRef]

61. Horvath, R.J.; Nutile-McMenemy, N.; Alkaitis, M.S.; Deleo, J.A. Differential migration, LPS-induced cytokine, chemokine, and NO expression in immortalized BV-2 and HAPI cell lines and primary microglial cultures. J. Neurochem. 2008, 107, 557-569. [CrossRef] [PubMed]

62. Henn, A.; Lund, S.; Hedtjärn, M.; Schrattenholz, A.; Pörzgen, P.; Leist, M. The suitability of BV2 cells as alternative model system for primary microglia cultures or for animal experiments examining brain inflammation. ALTEX 2009, 26, 83-94. [CrossRef] [PubMed]

63. Tornabene, T.G.; Bourne, T.F.; Raziuddin, S.; Ben-Amotz, A. Lipid and lipopolysaccharide constituents of cyanobacterium Spirulina platensis (Cyanophyceae, Nostocales). Mar. Ecol. Prog. Ser. 1985, 22, 121-125. [CrossRef]

64. Zavascki, A.P.; Goldani, L.Z.; Li, J.; Nation, R.L. Polymyxin B for the treatment of multidrug-resistant pathogens: A critical review. J. Antimicrob. Chemother. 2007, 60, 1206-1215. [CrossRef]

65. Kawasaki, T.; Kawai, T. Toll-like receptor signaling pathways. Front. Immunol. 2014, 5, 461. [CrossRef]

66. Youn, H.S.; Saitoh, S.I.; Miyake, K.; Hwang, D.H. Inhibition of homodimerization of Toll-like receptor 4 by curcumin. Biochem. Pharmacol. 2006, 72, 62-69. [CrossRef]

67. Minic, S.L.; Stanic-Vucinic, D.; Mihailovic, J.; Krstic, M.; Nikolic, M.R.; Cirkovic Velickovic, T. Digestion by pepsin releases biologically active chromopeptides from C-phycocyanin, a blue-colored biliprotein of microalga Spirulina. J. Proteom. 2016, 147, 132-139. [CrossRef]

68. Marín-Prida, J.; Pavón-Fuentes, N.; Llópiz-Arzuaga, A.; Fernández-Massó, J.R.; Delgado-Roche, L.; Mendoza-Marí, Y.; Santana, S.P.; Cruz-Ramírez, A.; Valenzuela-Silva, C.; Nazábal-Gálvez, M.; et al. Phycocyanobilin promotes PC12 cell survival and modulates immune and inflammatory genes and oxidative stress markers in acute cerebral hypoperfusion in rats. Toxicol. Appl. Pharmacol. 2013, 272, 49-60. [CrossRef]

69. Strasky, Z.; Zemankova, L.; Nemeckova, I.; Rathouska, J.; Wong, R.J.; Muchova, L.; Subhanova, I.; Vanikova, J.; Vanova, K.; Vitek, L.; et al. Spirulina platensis and phycocyanobilin activate atheroprotective heme oxygenase-1: A possible implication for atherogenesis. Food Funct. 2013, 4, 1586-1594. [CrossRef]

70. Zheng, J.; Inoguchi, T.; Sasaki, S.; Maeda, Y.; McCarty, M.F.; Fujii, M.; Ikeda, N.; Kobayashi, K.; Sonoda, N.; Takayanagi, R. Phycocyanin and phycocyanobilin from Spirulina platensis protect against diabetic nephropathy by inhibiting oxidative stress. Am. J. Physiol. Regul. Integr. Comp. Physiol. 2013, 304, R110-R120. [CrossRef] 
71. Koníčková, R.; Vaňková, K.; Vaníková, J.; Váňová, K.; Muchová, L.; Subhanová, I.; Zadinová, M.; Zelenka, J.; Dvořák, A.; Kolář, M.; et al. Anti-cancer effects of blue-green alga Spirulina platensis, a natural source of bilirubin-like tetrapyrrolic compounds. Ann. Hepatol. 2014, 13, 273-283. [CrossRef]

72. Cervantes-Llanos, M.; Lagumersindez-Denis, N.; Marín-Prida, J.; Pavón-Fuentes, N.; Falcon-Cama, V.; Piniella-Matamoros, B.; Camacho-Rodríguez, H.; Fernández-Massó, J.R.; Valenzuela-Silva, C.; Raíces-Cruz, I.; et al. Beneficial effects of oral administration of C-Phycocyanin and Phycocyanobilin in rodent models of experimental autoimmune encephalomyelitis. Life Sci. 2018, 194, 130-138. [CrossRef] [PubMed]

73. Matamoros, B.P.; Prida, J.M.; Rol, G.P. Nutraceutical and therapeutic potential of Phycocyanobilin for treating Alzheimer's disease. J. Biosci. 2021, 46, 42. [CrossRef]

74. Facci, L.; Barbierato, M.; Zusso, M.; Skaper, S.D.; Giusti, P. Serum amyloid A primes microglia for ATP-dependent interleukin-1 $\beta$ release. J. Neuroinflamm. 2018, 15, 164. [CrossRef]

75. Skehan, P.; Storeng, R.; Scudiero, D.; Monks, A.; McMahon, J.; Vistica, D.; Warren, J.T.; Bokesch, H.; Kenney, S.; Boyd, M.R. New colorimetric cytotoxicity assay for anticancer-drug screening. J. Natl. Cancer Inst. 1990, 82, 1107-1112. [CrossRef]

76. Piovan, A.; Filippini, R.; Corbioli, G.; Dalla Costa, V.; Giunco, E.M.V.; Burbello, G.; Pagetta, A.; Giusti, P.; Zusso, M. Carotenoid extract derived from Euglena gracilis overcomes lipopolysaccharide-induced neuroinflammation in microglia: Role of NF- $\mathrm{kB}$ and Nrf2 signaling pathways. Mol. Neurobiol. 2021, 58, 3515-3528. [CrossRef]

77. Barbierato, M.; Borri, M.; Facci, L.; Zusso, M.; Skaper, S.D.; Giusti, P. Expression and differential responsiveness of central nervous system glial cell populations to the acute phase protein serum amyloid A. Sci. Rep. 2017, 7, 12158. [CrossRef] 